"Trade-Related Aspects Of Intellectual Property Rights: Will The Uruguay Round Consensus Hold?"

Duncan Matthews

CSGR Working Paper No. 99/02

June 2002
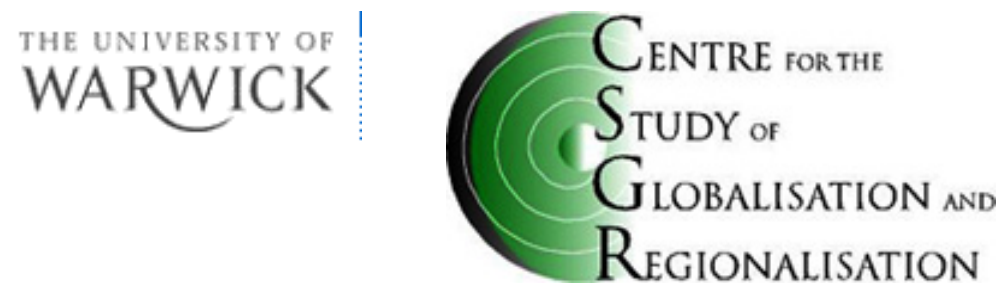


\title{
Trade-Related Aspects Of Intellectual Property Rights: Will The Uruguay Round Consensus Hold? \\ Duncan Matthews ${ }^{1}$ \\ School of Law, University of Warwick \\ CSGR Working Paper No 99/02
}

June 2002

\begin{abstract}
This paper reviews the building of a consensus in favour of the World Trade Organisation (WTO) Agreement on Trade-Related Aspects of Intellectual Property Rights (the TRIPs Agreement) during the Uruguay Round negotiations. The paper then argues that, at a time when the impact of TRIPs is becoming more widely understood in the developing world, the concentration of interests that secured the Agreement is now under pressure from a range of sources. The paper identifies institutions in the United States and Europe as playing a significant role as gatekeepers, balancing intellectual property interests against wider priorities in international diplomacy. The paper then suggests that the consensus between the United States and Europe has itself started to erode as a result of a series of on-going disputes. There has also been a fragmentation of the cross-sector industry consensus that led to business support for the TRIPs Agreement, while new actors whose views were peripheral to the Uruguay Round negotiations have now entered the debate on the impact of TRIPs. Finally, there are indications that, in interpreting the scope and meaning of the Agreement, WTO Dispute Settlement Panels themselves may be prepared to support a narrower interpretation of the TRIPs Agreement than the consensus builders first envisaged.
\end{abstract}

Keywords: intellectual property rights, trade, WTO, developing countries

\author{
Address for correspondence \\ Dr Duncan Matthews \\ School of Law \\ University of Warwick \\ Coventry, CV4 7AL, UK \\ Email: d.matthews@,warwick.ac.uk
}

\footnotetext{
${ }^{1}$ I am grateful to the Economic and Social Research Council Centre for the Study of Globalisation and Regionalisation at the University of Warwick for funding the research presented in this paper.
}

A more lengthy discussion of issues raised in this paper can be found in the following book: Duncan Matthews (2002) Globalising Intellectual Property Rights: The TRIPs Agreement (London: Routledge). 
This paper concerns the globalisation of intellectual property rights through the World Trade Organisation (WTO) Agreement on Trade-Related Aspects of Intellectual Property Rights (commonly referred to as the TRIPs Agreement). It is an account of the role played by global corporate actors (also known as multinational companies) in securing trade regulation capable of protecting global commercial interests to an extent not previously witnessed in relation to international protection of intellectual property rights. The paper explains how a consensus in favour of global action was achieved across a range of industry sectors, how a coherent strategy of industry alliances linked to government action then emerged, most visibly in the United States but also in Europe and Japan, and how a willingness to engage in forum shifting from bilateral to multilateral action, coupled with a negotiating advantage over developing countries in terms of intellectual property expertise, led to a successful outcome to the Uruguay Round of GATT negotiations as far as global business interests were concerned. In the light of the Uruguay Round negotiations that secured a TRIPs Agreement, the paper argues that global corporate actors have also played an important role in ensuring the effective implementation of the Agreement in each WTO Member country through surveillance carried out by their local branches and agents.

The paper suggests that, at a time when the impact of the TRIPs Agreement is becoming more widely understood in the developing world, the concentration of global business interests that achieved so much in securing the Agreement during the Uruguay Round negotiations is now under pressure that may lead it to fragment. The reasons for fragmentation of the global consensus amongst corporate actors are examined in detail. First, the paper identifies institutions in the United States and Europe as playing a significant role as gatekeepers that must balance the intellectual property concerns of business against wider priorities in international diplomacy. On several occasions, the result is that corporate complaints identifying inadequate intellectual property protection in developing countries have not been taken up by their home governments due to more pressing concerns relating to national security, political stability and economic development. Second, the paper suggests that the consensus between the United States and Europe has started to erode as a result of disputes relating to the continued use of bilateral trade sanctions by the US and due to an ongoing disagreement as to the most appropriate mechanism to be used for ascertaining the priority date for patent applications (first-to-invent or the first-to-file). Third, there has been a fragmentation of the cross-sector industry consensus that enabled business support for the TRIPs Agreement to appear so unequivocal in the first place. Fourth, new actors whose views 
were peripheral to the Uruguay Round negotiations have now entered the debate on global intellectual property protection more wholeheartedly in the wake of a wider understanding of the impact of the TRIPs Agreement. These new actors include: industry groups, such as generic drug manufacturers, that did not participate in the original negotiations; civil society groups including non-governmental organisations (NGOs), farmers groups and representatives of indigenous peoples that are raising awareness of the potential for adverse effects arising from the Agreement in terms of poverty and biodiversity; global institutions, such as the United Nations Conference on Trade and Development (UNCTAD) and the World Health Organisation (WHO), that have to some extent shared the concerns of civil society groups; and developing countries themselves who, through information deficiencies and lack of resources during the Uruguay Round negotiations, did not fully envisage the farreaching effect of the TRIPs Agreement and are now seeking renegotiation. Finally there are indications that, in interpreting the scope and meaning of the Agreement, WTO Dispute Settlement Panels themselves may be prepared to support a narrower interpretation of the TRIPs Agreement enforcement than global corporate actors envisaged, this narrower interpretation being restricted to flagrant violations as opposed, for example, to more general complaints that the 'legitimate expectations' of global corporate actors are not being met by the particular form of national implementing measure introduced to meet the requirements of the TRIPs Agreement.

It is against this background that the paper sets the scene for any renegotiation of the TRIPs Agreement, particularly during the forthcoming Doha Development Round of trade negotiations between WTO Members, identifying the likely negotiating platforms of key players and the range of issues likely to be at the forefront of future deliberations on international intellectual property protection. The paper examines the prospects for issues unresolved at the end of the Uruguay Round by virtue of being included but left open for review or omitted from the TRIPs Agreement altogether, assesses the likelihood of new issues being added (particularly in relation to biodiversity, indigenous knowledge and electronic commerce) and suggests that maintenance of the current text, with no substantive revision of the TRIPs Agreement, is the most likely outcome, but with amendments favourable to developing countries also a possibility. 


\section{BUSINESS SUPPORT FOR THE TRIPS AGREEMENT}

The TRIPs Agreement was made possible by the unprecedented support of business, which not only promoted the agreement but also contributed to its content (Evans 1994: 165). In truth, at the beginning of the GATT Uruguay Round of multilateral trade negotiations in 1986 few people in the Office of the United States Trade Representative (USTR) knew much about intellectual property (a view corroborated by Ryan 1998: 1). Instead, it was intense lobbying activity from industry, particularly in the US (Sell 1998: 137), that laid the foundations of linking intellectual property protection to trade in the multilateral context. As James R. Enyart, Director of International Affairs at Monsanto, put it: 'the rules of international commerce are far too important to leave up to government bureaucrats and their academic advisers. But governments, not businessmen, make rules and they only listen when the chorus gets big enough and the singing loud enough' (Enyart 1990: 53). So it was that patent and copyright business groups drove trade-related intellectual property policy in the 1980s and 1990s, although the diplomacy was conducted on their behalf by the USTR (Ryan 1998: 8). Pharmaceutical companies and copyright industries were amongst the most active of these groups because these sectors had relatively low entry barriers and consequently high exposure to piracy. High-level executives from activist companies representing these two industry groups - Ed Pratt, CEO of Pfizer and John Opel, CEO of IBM - were members of the US President's Advisory Committee on Trade Policy and Negotiations (ACTPN). The ACTPN was designed to provide direct input by the US business sector into US trade policy (Drahos 1995: 8).

\section{THE IPC AND IIPA}

The ACTPN was not only crucial to the development of a business strategy for international intellectual property protection on its own account. It was also significant because it served to focus attention on the fact that developing a new international code on intellectual property required the support of a nucleus of committed US companies with sufficient international business at stake to be willing to spend time and effort on the issue (Enyart 1990: 54). But while John Opel of IBM and Ed Pratt of Pfizer wanted to raise intellectual property as a trade issue through the work of the ACTPN, they did not immediately know how to articulate those concerns. It was here that the emergence of single-issue business groups proved so important in the history of the TRIPs Agreement. ${ }^{1}$ 
By the mid-1980s, US business was engaging in a strategic reorganisation of the way it articulated its complaints about piracy and counterfeiting abroad. In addition to organising themselves through the traditional route of sector-specific interest group representation, a further sphere of influence was sought through the formation of representative groups that represented a number of industries, bound together by the common goal of seeking to strengthen intellectual property protection in foreign markets. In effect, this new breed of representative group was an amalgamation of previously disparate industry groups. The most prominent of these were the Intellectual Property Committee (IPC), representing patentreliant industries in particular in the United States and the proprietary pharmaceutical industry in particular, and the International Intellectual Property Alliance (IIPA), representing the main copyright-reliant industries, including those operating in the film, music and publishing sectors.

The IPC grew out of the ACTPN (Braithwaite and Drahos 2000: 71) in the sense that it was Pratt and Opel, ACTPN members, who conceived the idea of an Intellectual Property Committee with a membership of Chief Executive Officers (CEOs) and funded directly from their companies (see also Enyart 1990: 54; Sell 1998: 137). The IPC comprised thirteen founding members: Pfizer; IBM; Merck; General Electric; DuPont; Warner Communications; Hewlett-Packard; Bristol-Meyers; FMC Corporation; General Motors; Johnson and Johnson; Monsanto; and Rockwell International. For the US film and pharmaceutical industries in particular, intellectual property was the backbone of their industries (Braithwaite and Drahos, 2000: 61). The IPC, run by Jacques Gorlin (a former Washington policy maker, consulting economist to IBM and later head of the Gorlin Group which continues to provide the secretariat for the IPC to this day), was (according to Ryan 1998: 9) well managed, well staffed, well funded and effective, with a single issue agenda that allowed it to be more focused, more flexible and responsive than traditional sector-specific trade associations (Enyart 1990: 54).

Unlike the IPC, the IIPA did not initially advocate a multilateral GATT-based approach to copyright protection, but instead favoured bilateral negotiations as the most effective means of strengthening enforcement of copyright protection in developing countries (Ryan 1998: 70). The IIPA, run by Eric Smith (a lawyer and Washington lobbyist), at that time represented the interests of eight trade associations: the Association of American Publishers; the Film Marketing Association; the Association of Data Processing Service Organisations; 
the Computer and Business Equipment Manufacturers Association; the International AntiCounterfeiting Coalition; the Motion Picture Association of America; the National Music Publishers' Association; and the Recording Industry Association of America. ${ }^{2}$ These trade associations, in turn, represented over 1,350 individual companies. The IIPA adopted a strategy of educating US policy makers who, they believed, knew a great deal about trade in real property goods but little about trade in intellectual property (Ryan 1998: 70).

With the objective of conveying to US policy makers the scale of losses to US industry resulting from piracy of copyrighted works, in 1985 the IIPA submitted a report entitled 'Piracy of US Copyrighted Works in Ten Selected Countries' to the ITC complaining about the detrimental effect of copyright piracy in Brazil, Egypt, Indonesia, Malaysia, Nigeria, the Philippines, the Republic of Korea, Singapore, Thailand and Taiwan (IIPA, 1985; see also Stewart 1993: 2254; Sell 1995: 164; Blakeney 1995: 78, 1996: 545; Ryan 1998: 71). In its report to the ITC, the IIPA estimated that the industries it represented collectively lost nearly $\$ 1.5$ billion annually as a result of inadequate copyright protection in the ten countries. Using figures supplied by the industry associations in the US, the IIPA estimated that the music industry alone lost over $\$ 600$ million per year, that the publishing industry lost over $\$ 400$ million per year, while the movie industry lost over $\$ 130$ million per year and the software industry over \$125 million (see also Stewart 1993: 2254). The IIPA called on the US government to establish an international trading environment in which intellectual property was respected and protected. By the mid-1980s, business pressure had brought intellectual property onto the political agenda and raised the profile of arguments that the government could best assist business by linking defence of their intellectual property rights to trade. Given the unsuccessful attempts to strengthen international conventions on intellectual property protection, the US initially sought this linkage through domestic trade law and bilateral trade agreements (Stewart 1993: 2255).

But before the GATT strategy could be set in motion, US policy makers faced a problem. Although copyright-dependent industries had also raised the profile of intellectual property as a trade issue, this time by forming the IIPA to identify quantifiable indicators and present statistical evidence (Ryan 1998: 10,69) to clearly send the message to policy makers that US copyright industries were losing out to piracy abroad, some copyright-based industries still adamantly opposed the idea of including copyright protection in GATT negotiations (Ryan 1998: 106). Since the problem for copyright-based industries was not with substantive 
provisions of national laws, but rather with lack of enforcement, the music, film and book publishing industries expressed a preference for bilateral trade negotiations and sanctions under Section 301 as the most flexible and effective means of improving enforcement levels (Ryan 1998: 107). Over a series of meetings with representatives with copyright-based industries, the USTR policy makers put the case for a multilateral negotiating strategy at the GATT, arguing the long-term benefits of a TRIPs Agreement. The advantages of such a move were two-fold: first, the inclusion of intellectual property within a multilateral trade agreement would give protection of those rights wide international coverage; and, second, the enforcement mechanisms of any such multilateral agreement would also be available for dealing with infringement of intellectual property rights (see also Braithwaite and Drahos, 2000: 61). Reluctantly, the copyright-dependent industries agreed to support a multilateral negotiating strategy (Ryan 1998: 107) although, crucially, this was to be along side rather than a replacement for the proven route of bilateral Section 301 action.

The next task was to get intellectual property onto the Uruguay Round GATT negotiating agenda. Government largely left this task to industry and their issue-specific groups, particularly the IPC. In September 1985 Jacques Gorlin wrote, in response to a request from the USTR, a review of the major issues involved in placing intellectual property into the next round of the GATT (see also Drahos 1995: 13). Gorlin's paper set out a possible model for a GATT code on intellectual property and outlined the problems that would need to be overcome if such a code were ever to be adopted (Drahos 1995: 12).

Since US business, represented by Pratt and Opel on the ACTPN, knew that any multilateral initiative would require the support of other developed countries (Braithwaite and Drahos 2000: 71), the first task for the IPC was to form alliances with business groups in Europe, initially through the Confederation of British Industries (CBI) in the UK, the Federation of German Industries (the BDI) in Germany and the Patronat in France. Through these national groups, the IPC then met with the Union of Industrial and Employers' Confederation of Europe (UNICE), which represented 33 national business federations at a European level. The IPC and UNICE then met with officials of the Japanese Federation of Economic Organisations (Keidanren), which represents virtually all business sectors and has good relations with the powerful Japanese Ministry of International Trade and Industry (MITI), with a view to gather international business support for pursuing a multilateral agreement on intellectual property protection and trade. ${ }^{3}$ Adopting a similar strategy to their US 
counterparts, UNICE and Keidanren were then able to use their contacts with policy makers in the European Communities and Japan to exert pressure aimed at building support for a multilateral agreement on intellectual property protection. This trilateral group of US, European and Japanese business interests was to prove crucial in distilling the fundamental principles of intellectual property contained in a practical code, written in the language of business (Enyart 1990: 55) that was to be so significant when submitted to the delegates to the GATT negotiations during the Uruguay Round. Without the support of European and Japanese business, the proposal for a TRIPs Agreement would never have been included in the Ministerial Declaration at Punta del Esta that set the agenda for the Uruguay Round (see also Braithwaite and Drahos 2000: 87).

Despite claims by some scholars in the United States (see, for instance, Ryan 1998: 107) that European and Japanese trade associations were reluctant to support the initiative and that neither they nor their governments were as committed to supporting the initiative as were some groups in the United States, in reality this was far from the case. European accounts of the actual discussions that took place between the IPC, UNICE and Keidanren paint a rather different picture. According to business representatives in Europe who recall the formulation of joint US, European and Japanese proposals, the three industry groups worked well together, not least because strong business interests in Europe were to be found in the pharmaceutical and book publishing sectors, while in Japan intellectual property protection for consumer electronics and software was crucial, all groups with a powerful interest in improving international intellectual property protection.

The differences that arose between positions of the IPC, UNICE and Keidanren were much more to do with the culture of lobbying and engaging with government on intellectual property matters. In Japan, the Keidanren shared the concerns of the IPC in relation to the growing problem of infringement of intellectual property rights but had no experience of taking issue with MITI on this type of issue. Similarly, the US model of lobbying for improvements in intellectual property protection was very different from the tradition of influencing public policy in the European Communities. While in the United States industry tends to have a relatively open and direct dialogue with government, in the EC there has been a greater tendency for business to make its views known via representative groups. The result is that, once the views of national industry associations have been articulated by UNICE, there is a likelihood that the case presented to policy makers may lack coherence and 
represent only a consensus view of the various national interests. As European Commission attempts to take into account the views of a far greater variety of national, industry and consumer interests in the EC face a much tougher task in influencing policy markers than do their counterparts dealing with the United States administration. But far from being reluctant to engage with their governments in support of an international agreement on intellectual property protection, during the early stages of formulating a coherent proposal for the TRIPs Agreement, the fact was that European and Japanese business interests simply behaved differently, though not necessarily with less enthusiasm, than their counterparts in the US business community.

Such is the under-representation of the role played by European business in accounts of the origins of the TRIPs Agreement emanating from the United States that, despite widespread acknowledgement that the initial drafting of the joint proposals was undertaken by Jacques Gorlin on behalf of the IPC and representing US business interests, the fact that John Beton, Chairman of the UNICE Intellectual Property Working Group, later re-wrote up to half of the original text on behalf of European business interests by the time a joint IPC, UNICE and Keidanren statement of views was ready for publication in $1988^{4}$ has been completely unrecognised.

In June 1988, nearly three years after Jacques Gorlin had drafted the initial paper on intellectual property at the GATT for IBM, the IPC, UNICE and Keidanren issued a joint statement of views on the 'Basic Framework of GATT Provisions on Intellectual Property' as a 'manifesto' (Drahos 1995: 14) that, it was hoped, would form the basis of a GATT intellectual property code. The Basic Framework (which later became generally known as the 'White Book' proposals) was presented to the GATT Secretariat as representing the coordinated views of the US, European and Japanese business communities. A consensus amongst business groups in developed countries had been achieved with relative ease. The Group of Ten developing countries, namely Argentina, Brazil, Cuba, Egypt, India, Nicaragua, Nigeria, Peru, Tanzania and Yugoslavia, meanwhile denounced the Basic Framework in general and its patent provisions in particular. India argued that developing countries should be free to exclude pharmaceutical products, food and chemicals from patent protection, shorten patent life for other sectors, and licence foreign patents under preferential terms (Ryan 1998: 110). India argued that a patent conferred in the host country was an obligation to undertake local working, with the use of compulsory licensing being recognised as a 
legitimate policy tool to prevent foreign companies from abusing their exclusive rights by relying on imports of patented goods. Despite these protestations, the demands of industry representatives made in the White Book proposals were clearly reflected in the final TRIPs Agreement (see Sell 1998: 138). The IPC claimed to have played a key advisory role, at the USTR's request, in developing the official US proposal on intellectual property that the US government tabled before the TRIPs Working groups in October 1987 (Weissman 1996: 1084).

While the ACTPN (and Ed Pratt, CEO of Pfizer, and John Opel, CEO of IBM, in particular) were working with Jacques Gorlin and the IPC to produce the legal ideas that underpinned the strategy of linking trade to intellectual property in the multilateral setting of GATT, Eric Smith and the IIPA continued to develop links between intellectual property and trade in the bilateral context (Braithwaite and Drahos 2000: 304). But despite complaints in 1986 from the USTR that other Quad members (the European Communities, Japan and Canada) were yet to be convinced about the need to include intellectual property in the Uruguay Round (Braithwaite and Drahos 2000: 204), that may have been the case with governments in the European Communities and Japan but it was certainly not the case with intellectual propertyreliant industries in those countries. The pharmaceutical, publishing and drinks industries in Europe, together with the software and computer games sectors in Japan, were all well advanced and articulate in expressing their views on the need for inclusion of intellectual property protection in the Uruguay Round. The IPC initiative proved so successful precisely because it duplicated views that were already prevalent about piracy and counterfeiting amongst key European and Japanese business sectors. In effect, the most important factor in the IPC's approach to European and Japanese business groups was above all the act of presenting exactly what global business wanted (in the 1988 Framework Document on Intellectual Property) at the right time to articulate the anxieties of global business interests.

\section{GLOBAL CORPORATE ACTORS AND IMPLEMENTATION OF THE TRIPS AGREEMENT}

For WTO Members, having recourse to the Dispute Settlement Procedure as a means to ensure effective implementation of the TRIPs Agreement has considerable benefits. However, from the perspective of business, the Dispute Settlement Procedures have the drawback that if a company or individual is aggrieved because of a failure to enforce the 
TRIPs Agreement in a particular foreign market, that company does not have locus standi, namely a right to bring an action before the WTO. While it is corporate intellectual property rights that are likely to be infringed if inadequate national intellectual property arrangements are in place, disputes are 'mediated' at the WTO through 'the agency of inter-governmental diplomacy' (May 2000: 72). Crucially, to have their complaints heard before the WTO, corporate actors face the constraint that they must petition their own national governments, as Members of the WTO, to bring an action through the Dispute Settlement Procedure on their behalf (see also Bello 1997: 357; Grubb 1999: 39; Macdonald-Brown and Ferera 1998: 70).

In the United States, the relationship between business and government is symbiotic: the absence of any private right of corporate actors to be heard as parties in complaints raised under the WTO Dispute Settlement Procedure ensures that business interests rely on government sponsorship of their cause while, conversely, corporate actors play a key role in providing information and advice on implementation and enforcement of the TRIPs Agreement in the territories of other WTO Members to an under-resourced and overstretched USTR. Companies with global interests continually feed information to organisations such as the IIPA, IPC about intellectual property infringements in foreign markets (see also Braithwaite and Drahos 2000: 87) which in turn present recommendations to the USTR. The USTR then undertakes an inter-agency review of the issues (see also Bello 1997: 357). Complaints raised by business interests are then articulated by the USTR through the Special 301 process, TRIPs Council scrutiny procedures and through the WTO Dispute Settlement Procedure. The role of corporate actors and their representative business groups in monitoring implementation of TRIPs provisions - and alerting the USTR as to the need to consider both Special 301 measures and complaints under the WTO Dispute Settlement Procedure against recalcitrant states - is therefore crucial to the whole implementation process. $^{5}$

In the wake of their role in the formulation of the TRIPs Agreement, it is the single-issue groups representing corporate intellectual property interests, particularly the IPC and the IIPA, that have now re-invented themselves as guardians of TRIPs implementation. Despite the decision of some companies not to remain members of the IPC once the core objectives of securing the TRIPs Agreement had been achieved on the basis that this no longer represents good value for money, ${ }^{6}$ the redefinition of the roles played by the single-issue groups has proved generally successful in maintaining the momentum of membership involvement and 
the USTR still values the work of these single-issue interest groups. ${ }^{7}$ In addition to the IPC and IIPA, which provide representation for the US patent and copyright industries respectively, the International Trademark Association (INTA) operates a 'TRIPs 2000 Subcommittee'. The INTA Subcommittee has, for example, produced a detailed assessment of the level of compliance with the TRIPs Agreement in over 60 countries (International Trademark Association 1999), finding that enforcement remains problematic in many developing countries

It is through their networks of local branches, agents and representatives worldwide that business interests represented by organisations such as the IPC, IIPA and INTA provide the USTR with a detailed accurate picture of intellectual property standards in their respective markets. Copyright-reliant industries such as the phonographic and video movie industries represented by the IIPA, where the cost of reproducing high quality pirated copies is relatively low, have been particularly 'aggressive' (Ryan 1998: 155) in enforcing their intellectual property rights through global networks of surveillance, public awareness campaigns and pressure exerted on the governments of recalcitrant WTO Members and via complaints to the USTR, with the associated threat of Special 301 actions.

Furthermore, once WTO Member countries have put in place the required measures to ensure effective enforcement, the 'unstated inference' (Reichman 1996: 369) is that private domestic enforcement actions, brought by rights holders under domestic law, will augment the topdown role of the TRIPs Council and reduce the need for Dispute Settlement actions. Civil litigation brought by businesses operating in local markets has the potential to assist in ensuring effective enforcement of intellectual property protection. Yet doubts remain as to whether this system will work effectively in practice given that, in the majority of countries, intellectual property actions are dealt with by non-specialist district courts that are often alleged to be unsympathetic to foreign owners of intellectual property rights (see Waters 1996: 767).

Global corporate actors, particularly proprietary pharmaceutical manufacturers, also operate an effective network of global surveillance through on-going relationships with local firms of patent attorneys. It is these local agents who are well placed to provide multinational companies with information about changes to domestic law. However, the value of this information resource should not be overstated. Information provided by local agents is of 
variable quality and it is often the case that the patent attorneys who are best placed to know about changes to domestic intellectual property law are those attached to large legal firms that conduct general litigation work as opposed to those which concentrate simply upon patent application procedures locally.

Global surveillance of copyright infringement suffered by US owners is coordinated by the IIPA, which submits a detailed annual report on copyright infringement and piracy worldwide to the USTR by way of background information and recommendations prior to the USTR's decisions on initiating the Special 301 procedure or complaints to the WTO Dispute Settlement Body. As it did in the pre-TRIPs international legal landscape, the IIPA continues to highlight piracy losses on both a regional and global basis, emphasising industry variations and the economic impact of losses (see, for example, International Intellectual Property Alliance 1998 and Smith 1996: 559). The IIPA is assisted in the preparation of its reports by a network of US trade associations whose member companies, operating through branches, subsidiaries and agents in local markets, are the actors best placed to provide an accurate (if unverified) account of local trading conditions and intellectual property infringements. The motion picture, music, book and software industries are particularly active in this respect (see also Ryan 1998: 71). The IIPA collates information it receives from its member trade associations and undertakes lobbying activities on their behalf with the aid of estimates of losses to US industry abroad. In 1998 the IIPA estimated that losses to the US economy in the previous year as a result of copyright infringement amounted to almost $\$ 10.8$ billion, ${ }^{8}$ of which the motion picture industry estimated losses of $\$ 1,584$ million; the sound recordings and music industry $\$ 1,321.8$ million; computer programs and business applications $\$ 3,964.4$ million; games and entertainment software \$3,249.2 million; and book publishing $\$ 664.1$ million. ${ }^{9}$

A similar report is prepared annually by the Pharmaceutical Research and Manufacturers of America (PhRMA), which each year produces a country-by-country assessment for the USTR detailing intellectual property infringement abroad likely to lead to losses to the US proprietary pharmaceutical industry. ${ }^{10}$ In 1998, for example, the PhRMA estimated that annual losses in Argentina and India due to the absence of patent protection for pharmaceutical products amounted to approximately $\$ 500$ million in each country. ${ }^{11}$ 
On receipt of complaints relating to intellectual property infringement, the role that the USTR engages in to manage its relations with corporate actors is very much that of an institutional 'gatekeeper' (Bello 1997: 359). As in the case of the European Communities, US policy makers are often constrained by wider issues of political diplomacy when considering whether to act on complaints by private business interests regarding TRIPs Agreement implementation problems. Judith Bello, for instance, (who served as General Counsel and Deputy General Counsel at the USTR between 1985 and 1989) has acknowledged that security issues and foreign policy matters may well influence the United States administration's decision on whether or not to bring a complaint against another WTO Member under the Dispute Settlement Procedure (Bello 1997: 357). The significance of international politics in determining whether or not WTO Members will be the subject of US complaints under the Dispute Settlement Procedure was corroborated during the research for this paper.

US business representatives complained that US policy towards developing countries on compliance with the TRIPs Agreement is 'blunted' by the fact that the USTR is not the only agency in the US administration with an interest in, for example, South America and South Africa. The USTR has been slow to take action against Argentina ${ }^{12}$ for inadequate patent protection of pharmaceutical products and against South Africa for measures allowing parallel imports. This reluctance to act on the part of the USTR has been attributed to the wider diplomatic significance of a US strategic ally in South American (in the case of Argentina) and the rebuilding of political institutions in South Africa following the ending of apartheid. Turkey is also described as being 'untouchable' by US business interests because its value as a member of NATO far outweighs the inadequacy of measures taken to achieve effective intellectual property protection.

Within the federal government administration, the formal mechanism for coordinating intellectual policy is a Sub-Committee of the Trade Policy Staff Committee (TPSC). This is chaired by the Director of Intellectual Property at the USTR and comprises representatives of the Treasury, Commerce, State and Labor Departments. In theory, tensions between competing departmental interests in relation to intellectual property protection are dealt with by the TPSC, the Trade Policy Review Group (TPRG), chaired by the Deputy USTR, or by the National Economic Council. However, the frustration of US business representatives is that, in practice, the USTR is perceived to be a relatively weak institutional actor in 
comparison with the State Department and the Defense Department, lacking the political constituency to limit the intervention of other parts of the administration on trade issues. The overall result of this complex web of security issues, diplomatic imperatives and interdepartmental priorities is that the decision not to act on the basis of complaints from business relating to infringement of intellectual property rights will, on occasion, win out over US corporate interests.

If the US administration does agree to bring a case before the WTO Dispute Settlement Procedure, corporate interests and the USTR-led inter-agency government team (Bello 1997: 357) then co-operate closely in drafting the request for consultations with the WTO Member in question and, if those informal consultations do not adequately rectify the problem, in the formulation of the complaint made by the US delegation to the WTO at meetings of the Dispute Settlement Body. In practice, although the USTR will take the lead in representing the United States before a panel in the WTO Dispute Settlement Procedure, it will do so only after closely consulting with corporate interests at home, who in turn have generated the original complaint and are well placed to provide technical expertise and specialist knowledge throughout the course of a the WTO Dispute Settlement Panel's deliberations (see also Bello 1997: 361).

Although few disputes have so far been initiated in relation to the TRIPs Agreement, with only four panels so far concluding their deliberations in instances of complaints relating to non-compliance with TRIPs Agreement obligations, the significance of the dispute settlement mechanism as a means of ensuring that Members provide effective enforcement is already clear. It offers a far more effective mechanism than that available under the previous GATT 1947 provisions (see Gutowski 1999: 743).

\section{SIGNS OF FRAGMENTATION OF THE GLOBAL CORPORATE CONSENSUS}

Despite a trend for global corporate actors seeking to overcome institutional and political constraints by forming strategic alliances and engaging in a dual strategy of US and EC complaints, or even forum-shifting from the US to EC in relation to patent protection for pharmaceutical products, in the copyright sector, complaints raised by US companies in relation to standards of intellectual property protection in the EC have marked a move a way from the dual strategy of global corporate actors utilising both US and EC routes to influence 
foreign governments. In the copyright sector it is European states that have found themselves falling foul of complaints by the United States. The cracks in the Uruguay Round consensus between business and policy makers in the US and EC became apparent as early as 1997 when the Business Software Alliance (BSA), which represents the interests of the US computer software industry, played a significant role in mobilising US government officials to enter into the consultations with Sweden concerning the latter's failure to fulfil obligations under the TRIPs Agreement. The US complaint concerned Articles 50, 63 and 64 of the TRIPs Agreement, under which WTO Members are required to make available ex parte provisions in civil proceedings. This requires national courts to impose provisional measures in order to prevent infringements and to preserve evidence (see Dörmer 2000: 24).

On 18 May 1997 the US requested consultations with Sweden ${ }^{13}$ regarding the failure of anton pillar orders under Swedish law to allow sufficient scope for premises to be searched without warning in order to determine if an infringement of intellectual property rights had taken place. ${ }^{14}$ In response, on 25 November 1998 the Swedish Parliament adopted legislation that amended Swedish intellectual property law to allow a court to grant an anton piller order to a search for evidence of infringement if there is reason to believe that an individual has or soon will infringe intellectual property rights (see also Geuze and Wager 1999: 381; Gutowski 1999: 740). On 2 December 1998 this enabled the US and Sweden to notify the WTO Dispute Settlement Body that the issue had been resolved.

What is particularly notable about this case is that, in its objections to Swedish legislation implementing the TRIPs Agreement, it was the software industry, through the BSA and the International Chamber of Commerce, which instigated the complaint. Although resolved without recourse to the formal WTO Dispute Settlement Procedure, this complaint was seen in the European Communities as an attempt by US software companies to create a legal environment sympathetic to their interests, motivated by the desire to ensure that users products licensed by their member companies were actually paying for software used through legitimate means in the face of the European tradition of guarding against abuses of anton piller orders by maintaining restrictive provisions on their use.

Further evidence of the fragmentation of the US-EC consensus, at least in relation to copyright protection, can be seen in relation to copyright protection for films and television broadcasts. Following a complaint from the Motion Picture Association of America (MPAA) 
the United States requested consultations with Greece ${ }^{15}$ on 30 April 1998, and a parallel request for consultations with the European Communities, ${ }^{16}$ claiming inadequate copyright protection for films and television programmes broadcasts by TV companies in Greece (see Dörmer 2000: 25).

Most recently, the European Communities complained that the United States had failed to meet its copyright obligations under the TRIPs Agreement. On 26 January 1999, the European Communities, later joined as third parties by Australia, Brazil, Canada, Japan and Switzerland, complained to the Dispute Settlement Body that Section 110(5) of the United States Copyright Act, as amended by the Fairness in Music Licensing Act of 27 October 1998, ran contrary to Article 13 of the TRIPs Agreement and therefore was not consistent with the Berne Convention, as incorporated into the TRIPs Agreement by Article 9.1. The amended Section 110(5) contained an exception to the exclusive rights of copyright holders in instances where copyrighted work was communication to the public in commercial premises on 'homestyle' audio-visual equipment (the type of receiving equipment commonly used in private homes). On 15 June 2000 the Dispute Settlement Panel upheld the main substantive elements of the complaint ${ }^{17}$ and, as a result, the United States was required to bring the 'homestyle' provisions of its Copyright Act into conformity with its obligations under the TRIPs Agreement.

\section{WILL THE URUGUAY ROUND CONSENSUS HOLD?}

Global corporate actors see the TRIPs Agreement as a major achievement. It is certainly true that, by raising intellectual property as a significant issue for international trade during the Uruguay Round, business interests in developed countries demonstrated a remarkable propensity to engage in alliance building, achieving a consensus in favour of improved international intellectual property protection that was to hold firm throughout negotiations for the TRIPs Agreement. Corporate actors also showed themselves to be astute negotiators, recognising early on the importance of strategic repositioning and forum shifting from an initial bilateral approach reliant on US trade legislation to a multilateral approach involving US, European and Japanese actors with the objective of linking intellectual property to trade through the Uruguay Round of GATT. The consensus achieved demonstrated the heterogeneity of corporate interests worldwide and raised intellectual property rights as a new agenda item for international trade negotiations. Without the global corporate consensus there 
quite simply would have been no WTO Agreement on Trade-Related Aspects of Intellectual Property Rights. Technical support provided by industry experts was also crucial, providing US and EC delegations to the Uruguay Round with the detailed practical knowledge of intellectual property rights that public officials on occasion lacked.

There is now a risk, however, that although global corporate actors are working hard to maintain the momentum that made possible the achievements of the Uruguay Round, those efforts may be undermined by a fragmentation of the very consensus amongst global corporate actors and developed country governments that made the TRIPs Agreement possible in the first place. This section of the paper considers the extent to which global business interests have been able to hold together the industry consensus that proved so significant during the Uruguay Round negotiations. It also considers the extent to which fragmentation of the consensus has been precipitated by a range of pressures both internal to the global business community and external to it.

\section{The Transatlantic Business Dialogue}

At the outset it must be acknowledged that, to a large extent, the common interests that made possible the Uruguay Round consensus still exist. Global corporate actors and developed countries have worked hard on preparations for a review of the built-in agenda of the TRIPs Agreement. At the same time monitoring implementation and enforcement has become a high priority following the expiration of the Article 65 transitional arrangements for developing countries. One of the main venues for maintaining the global business consensus on these issues has been the Transatlantic Business Dialogue (TABD). The TABD, which held its first conference in Seville in November 1995, was initially conceived as a mechanism through which companies and business associations could develop joint US-EC trade policy recommendations by working together with the European Commission and the US Administration. The TABD now involves representatives of a range of companies in the United States and Europe that have transatlantic commercial interests. It seeks to offer a framework for cooperation between the transatlantic business community and the governments of the US and EC across a range of issues including: standards, certification and regulatory policy; market access; government procurement, investment; business practices; export controls; taxation; customs; small and medium sized enterprises; and intellectual property rights. ${ }^{18}$ 
With respect to intellectual property rights, the TABD has provided a forum for dealing with unresolved issues on intellectual property protection in respect to deficiencies in both bilateral and multilateral arrangements. In May 1996, under the auspices of its Intellectual Property Issues Group, the TABD produced an interim report on what needed to be done to revise the TRIPs Agreement. By October 1997 those interim findings had been formalised, at a symposium involving officials from the US government and the European Commission, into an Intellectual Property Issues Group Action Plan. Amongst the recommendations contained in the Action Plan were an undertaking that the US and EC should work together at both government and industry levels to coordinate efforts to provide training and technical assistance designed to assist developing countries in meeting their obligations in accordance with Article 67 of the TRIPs Agreement. The Action Plan also recognised the importance of effective enforcement mechanisms as a means of reducing piracy levels through remedies, damages and criminal penalties.

By November 1996 the aims of the Action Plan were formalised in the TABD Chicago Declaration, which included calls on the US and EC to launch efforts to ensure accelerated implementation of TRIPs obligations in developing countries and to achieve maintenance of non-discriminatory regimes conducive to full market access for intellectual property protected products. Chicago also set in motion the process of drafting a so-called 'Living Annex' to the Declaration, setting out the deficiencies in intellectual property protection and enforcement in developing countries that the TABD wished to bring to the attention of the US and EC authorities. In the Annex, the TABD identified countries having deficiencies in their intellectual property protection and enforcement resulting in significant commercial losses to industry. The Annex remains undated so that it can be regularly updated, with initial priority given to those countries representing the most important markets for US and EC business, namely: Argentina; Brazil; Canada; Hungary; Israel; India; Indonesia; Japan; Mexico; the People's Republic of China; the Russian Federation; and Turkey.

In addition to the TABD's concerns about inadequate intellectual property protection in developing countries, the Living Annex sets out a range of differences between the US and EC, where first-to-file continues to be a major issue within patent harmonisation. The US, it will be recalled, has a patent system based on the principle of first-to-invent with the result that, from the EC perspective, legal uncertainty and additional costs are introduced into the patent system. ${ }^{19}$ The European Commission initiative on a 'New Transatlantic Marketplace ${ }^{20}$ 
raised the stakes on first-to-invent further in March 1998, describing the US system as 'anachronistic' and 'extremely demanding in terms of evidence for all inventive activities'. ${ }^{21}$ The significance of these differences between the US and EC as factors contributing to fragmentation of the Uruguay Round consensus is discussed later in the paper.

\section{The IPC and the 'Millennium timebomb'}

A related initiative proposal to focus the attention of the business community on implementation and enforcement of the TRIPs Agreement in developing countries was initiated in February 1998 when the IPC, which spearheaded the original business transatlantic initiative during negotiations for the TRIPs Agreement, proposed to UNICE that TRIPs implementation issues should mark a continuation of the IPC-UNICE alliance that had worked so successfully during TRIPs negotiations. The IPC proposal resulted in what became known as the 'Gorlin Draft', an international strategy which sought to prevent a 'Millennium timebomb' of developing countries coming forward in accordance with the Article 63 TRIPs Council review procedure on 1 January 2000 to demonstrate the conformity of national measures taken to ensure effective enforcement of the TRIPs Agreement. In practice the IPC and UNICE feared that developing countries would be unable to provide evidence that those enforcement levels had been met, effectively extending the transitional periods available for developing country compliance. ${ }^{22}$ In addition, the Gorlin Draft anticipated that the WTO Dispute Settlement Procedure would be overwhelmed by a flood of WTO intellectual property complaints with the result that the effectiveness of the WTO to develop and enforce international rules would be seriously called into question.

The strategy recommended in the Gorlin Draft was four-fold: first, that industry should seek to activate governments, namely to encourage the WTO delegations from the developed world to put pressure on developing countries in the TRIPs Council to ensure effective enforcement; second, to initiate a process by which representatives from industry would participate in regional conferences designed to raise awareness of the significance of intellectual property protection in developing countries; third, to ensure that industry continued to engage bilateral investigations, namely monitoring and surveillance exercises to ascertain whether developing countries were meeting their obligations under the TRIPs Agreement; and, fourth, to encourage the provision of technical assistance to developing countries via industry involvement in initiatives undertaken by WIPO, public awareness campaigns and Embassy programmes organised in developing countries. 
The Gorlin Draft resulted, on 5 May 1998, in the issuance of a joint IPC-UNICE statement, expressing concern that a large number of developing countries would not have adopted the laws and regulations necessary to bring them into compliance with the TRIPs Agreement by the ending of the Article 65 transitional arrangements. The joint statement concluded by calling on the European Commission and the US and European governments to intensify their efforts to ensure proper and timely TRIPs implementation in developing countries.

Global business has also continued to press its case for close scrutiny of developing country implementation and enforcement of the TRIPs Agreement through a direct dialogue with the WTO Secretariat in Geneva. In September 1998 a joint IPC-UNICE delegation travelled to Geneva to advise the TRIPs Secretariat on industry priorities, particularly in relation to ensuring that all obligations under the TRIPs Agreement are complied with before undertaking a new round of WTO trade negotiations and making recommendations as to how to avert a 'Millennium timebomb' in developing countries. That delegation from the business community included Jacques Gorlin of the IPC and strong representation from the global proprietary pharmaceutical industry in the form of patent experts from GlaxoWellcome and Pfizer.

\section{The pharmaceutical industry: pipeline protection and supplementary protection certificates}

The global proprietary pharmaceutical industry has also been active in seeking refinement of the TRIPs Agreement with calls for pipeline protection for medicinal products and improvements to the arrangements under TRIPs for the handling of confidential information required for regulatory approval. Article 39.3 requires that Members protect undisclosed test or other information against unfair commercial use, except where necessary to protect the public, during the process of approving the marketing of new pharmaceutical or agricultural chemical products that utilise new chemical entities. The omission of a fixed period of protection for data included in regulatory submissions leaves open the prospect of individual countries offering lax standards, given that discretion as to the length of duration for data protection is to be retained by WTO Members. The pharmaceutical industry in the UK has been particularly critical of Article 39.3 on grounds that it provides insufficient protection for information provided as regulatory submissions because the TRIPs Agreement provides insufficient clarity as to the term of protection that is required. In most EC countries, including the UK, ten-year protection exists, with Spain increasing its term of protection from 
six to ten years at the end of the 1990s. Nevertheless, Portugal and Spain continue to offer protection for a maximum of six years, while data protection for regulatory submissions in the United States only operates for a five-year period.

Similarly, the global pharmaceutical industry remains dissatisfied that the TRIPs Agreement does not provide for an extension to the term of patent protection equivalent to the five-year supplementary extension certificates that are available for pharmaceutical and agricultural chemical products in, for instance, the UK, the US and Japan. In this respect, the TRIPs Agreement merely provides for a basic 20-year period of patent protection which, it is argued by industry, fails to take account of the regulatory approval procedures that new drugs and chemical substances must undergo for a number of years before they can be made available on the market. The reason why supplementary extensions to the duration of patent life were not included in the TRIPs Agreement appears to have been that, having moved from a preTRIPs situation in which more pressing issues such use of compulsory licences, had been dealt with to the benefit of the pharmaceutical and agricultural chemical industries, it was then difficult to sustain a negotiating position to the effect that these same companies should benefit from positive discrimination in the form of supplementary patent certificates.

\section{SIGNS OF FRAGMENTATION IN THE URUGUAY ROUND CONSENSUS ON INTELLECTUAL PROPERTY}

In the wake of the successes of global corporate actors and developed country governments in terms of achieving consensus on the need for a TRIPs Agreement during the Uruguay Round, there are indications that the consensus is now beginning to fragment. These signs of fragmentation can be categorised into the following sets of issues: the role of institutions as gatekeepers, principally the USTR and the EC's Article 113 Committee which must respond to the wider imperatives of international diplomacy in addition to safeguarding the intellectual property interests of its nationals abroad; factors internal to the global business community that have lead to cracks in the Uruguay Round consensus previously enjoyed during TRIPs negotiations; factors external to the global business community in the form of entry by new actors that have been mobilised since the end of the Uruguay Round; and the impact of Reports issued by Dispute Settlement Panels of the WTO that have limited the scope of complaints that have been allowed relating to the TRIPs Agreement. This section examines each of these sets of issues in turn. 


\section{INSTITUTIONS AS GATEKEEPERS}

\section{The limits of international diplomacy}

As discussed earlier in the paper, the role that the USTR engages in to manage its relations with corporate actors is very much that of an institutional 'gatekeeper', with US policy makers often constrained by wider issues of political diplomacy when considering whether to act on complaints by private business interests regarding TRIPs Agreement implementation problems. This gatekeeper role creates a situation in which, by using its discretionary powers to decide whether to bring complaints relating to compliance with the TRIPs Agreement before the WTO, the US Administration will be mindful of wider issues relating to national security and foreign policy. Policy issues outside the scope of trade relations therefore have a considerable potential to influence the United States Administration's decision on whether or not to bring a complaint against another WTO Member under the Dispute Settlement Procedure.

As a result, US corporate actors have complained that the stated US policy of ensuring compliance with the TRIPs Agreement is hindered by wider concerns relating to international diplomacy, with the USTR not the only agency in the Administration with an interest in developing countries. The result has been that the USTR has in the past been reluctant to initiate complaints against Argentina for inadequate patent protection of pharmaceutical products or against South Africa for measures allowing parallel imports and arrangements for granting compulsory licensing for pharmaceutical products. This reluctance to act on the part of the USTR remains a source of frustration for corporate actors that fear the achievements of the TRIPs Agreement will be undermined if the US Administration continues to allow wider diplomatic concerns to take precedence over the need to ensure effective intellectual property protection via complaints to the Dispute Settlement Body.

Similar diplomatic constraints have been encountered in the European Communities, where the Article 113 Committee procedure in principle offers a mechanism for action against recalcitrant trading partners with each EC Member State holding the procedural right to ask the Commission to investigate allegations of inadequate intellectual property protection in non-Member States. As in the United States, however, international diplomacy often creates problems leading to inaction against recalcitrant third countries. Since unanimity amongst the 15 EC Member States is required before the Article 113 Committee can decide to take action 
against a country deemed to provide inadequate protection of intellectual property rights, the reality is that at any given moment it is likely that at least one Member State at a sensitive stage in its relations with a country that will lead it to step back from supporting the sanctioning of action by the Article 113 Committee. In this respect, the Committee frequently acts as a 'gatekeeper' in much the same way as the USTR, filtering out complaints based on grounds of inadequate intellectual property protection where international relations concerns take primacy over narrower trade issues.

\section{DISPUTES BETWEEN ACTORS IN DEVELOPED COUNTRIES}

For many global corporate actors, trade-related intellectual property rights have now ceased to be an issue deemed to be of sufficient urgency to garner consensus amongst an otherwise disparate corporate lobby in its relations with government policy makers with regard to trade matters. In this respect, the TRIPs Agreement is seen by many of the key players involved in building business consensus in the run-up to the Uruguay Round as being only achievable at a particular moment in time through a coming together of pan-industry global business interests.

Some credence can be accorded to the view that the developed country consensus that lay at the heart of the TRIPs Agreement has begun to show increasing signs of strain since the conclusion of the Uruguay Round if one observes the series of complaints brought before the WTO Dispute Settlement Body. As predicted by Reichman (1995: 390), the TRIPs Agreement has set developed countries against other developed countries. In addition to the disputes already, the European Communities has made complaints to the DSB in relation to Sections 301-310 of US Trade Act of $1974^{23}$ and in relation to Section 110(5) of the US Copyright Act, ${ }^{24}$ while and the United States has made a complaint in relation to Section 44 of the Canadian Patent Act. ${ }^{25}$ These disputes between developed country governments have dominated Dispute Settlement Panels' deliberations in relation to the TRIPs Agreement to an extent that is surprising, even given that the existence of transitional periods under Article 65 of the TRIPs Agreement may thus far have limited the number of disputes involving developing countries.

Even outside the realm of Dispute Settlement Panels, tensions between the US and EC were apparent as early as March 1998, when European Commissioner Sir Leon Brittan announced 
proposals for a new US-Europe trade area. The Brittan proposals highlighted the differences between the US and EC on first-to-file and were criticised by many intellectual property experts in the corporate sector precisely because they raised the differences between US and EC business interests at the expense of an opportunity to present a common front against poor intellectual property protection in developing countries. Given that the EC has continued to put pressure on the US bilaterally to adopt a first-to-file procedure, the issue appears likely to continue to be divisive and has significant potential to undermine developed country consensus during any future review of the TRIPs Agreement (see also Watal 1999: 17).

The potential of the first-to-file debate to undermine developed country consensus is also apparent at the level of the TABD. While there have been calls from IPC and Interpat for the TABD to become a more co-operative forum in which the interests of business in the US and EC can be co-ordinated so as to present a unified voice to developing country governments, in practice companies have criticised the tendency for the TABD to spend too much time and effort trying to resolve the first-to-file issue. Even where the TABD has been able to act coherently in relation to intellectual property protection, such as via the 'Living Annex' to the Chicago Declaration, there are concerns amongst the business community that this strategy of putting pressure on developing countries can be counterproductive, sending the wrong message by indicating that global corporate actors are exerting undue pressure to improve intellectual property protection within developing countries in a manner which is interpreted as challenging developing countries' national sovereignty.

The immediate task for groups representing global business interests must be to ensure that developing countries have fulfilled their obligations at the end of the transitional period, then worry about what the terms of the TRIPs Agreement actually require later, finally dealing with 'wish lists' of what the TRIPs Agreement would look like in an ideal world. Yet although the remit of single-issue groups representing business interests, such as the IPC and IIPA, now includes monitoring implementation of the TRIPs Agreement in developing countries, in practice companies are now more focused on industry-specific intellectual property issues. While the key to the success in getting intellectual property protection onto the Uruguay Round agenda and subsequently achieving the terms set out in the TRIPs Agreement was the cohesiveness of US industry and its willingness to speak with one voice, the pre-TRIPs Agreement consensus across industries on a global scale has now become more focused on gaining competitive advantage than on common goals. Even within industry 
sectors, there are signs of tension in the previously solid pro-TRIPs Uruguay Round consensus. On pipeline protection, for example, individual proprietary pharmaceutical companies are seeking to gain competitive advantage by disputing when retroactive effect should take effect, with arguments centring on commencing retroactivity depending on when their own patents and those of their competitor firms were first filed.

\section{ENTRY OF NEW ACTORS}

The global corporate consensus in favour of the TRIPs Agreement also faces threats as new actors, namely industries, non-governmental organisations, WTO Members and international institutions not active during the Uruguay Round process in relation to intellectual property negotiations, enter the debate on the future of TRIPs.

\section{Generic drug companies}

Of particular significance amongst these new actors are generic drug manufacturers that have entered the debate on the current impact and future reform of the TRIPs Agreement in a concerted manner since the end of the Uruguay Round, becoming better organised and more likely to present the generic industry's viewpoint on an international scale (Waters 1996: 771). In the pharmaceutical sector, the impact of a better coordinated and more articulate generic drug industry is that proprietary companies no longer have a clear route of access to government in relation to public policy on international intellectual property protection. There is also concern amongst proprietary pharmaceutical companies that generic companies are already thinking about how to work at the margins of the TRIPs Agreement, using loopholes and interpretations of the text in a manner capable of allowing competitive advantage to accrue to manufacturers of off-patent pharmaceutical products. There may be some genuine grounds for these concerns given the attempted interpretation of Bolar exemptions and related stockpiling provisions in Canada, Israel and Cyprus.

\section{NGOs}

NGOs with concerns about the impact of the TRIPs Agreement in relation to health care, developmental and environmental issues (see also Newell 2000: 117) are increasingly articulating their views in a way that was almost entirely absent during the Uruguay Round negotiations leading to the TRIPs Agreement. These NGOs are likely to enjoy a much higher 
profile during the Doha Development Round of WTO negotiations, not least because the WTO is now anxious to improve the legitimacy of its activities through interaction with civil society groups. ${ }^{26}$ NGOs are, for their part, seeking to provide a voice capable of speaking up for of developing countries (see also Abbott 1996: 400) that were perceived as lacking negotiating expertise and bargaining power during the Uruguay Round. In this respect, USbased groups such as the International Forum on Globalization ${ }^{27}$ and Public Citizen ${ }^{28}$ have been active in predicting that the TRIPs Agreement will have adverse effects on developing countries, particularly due to rising consumer prices, infringements on the rights of indigenous peoples and adverse effects on biodiversity (see also Drahos 1997: 206). Blakeney (2001: 540) also describes the work of the federation of indigenous peoples groups that, on 25 July 1999, issued a statement expressing concern that Article 27.3(b) of the TRIPS Agreement would further denigrate and undermine their rights to cultural and intellectual heritage. A coalition of NGOs and local groups in developing countries is therefore highlighting the likelihood of a negative effect of the Agreement in a way that was simply not evident during the Uruguay Round negotiations. ${ }^{29}$

The perceived plight of farmers in developing countries is a case in point. The crucial international agreement relating to farmers in developing countries is the UPOV Convention on Plant Breeders' Rights that, although not explicitly mentioned in the TRIPs Agreement, has been widely taken as a model for many developing countries that opt to exclude from patentability plant varieties, relying instead on a sui generis as specified in Article 27.3(b). Adopting the UPOV Convention on the basis that it offers the most readily available form of sui generis protection, however, has drawbacks for developing country farmers. The UPOV Convention has been revised three times, in 1972, 1978 and 1991. Although the last revision of the Convention is still acknowledged as being far less extensive in scope than the TRIPs Agreement provisions on patent protection (Pacón 1996: 345), in a move described by Reichman (1995: 359) as having 'elevated these standards of protection from a modified copyright model to a modified patent model', WTO Members opting to become signatories to the 1991 version of UPOV as a means of avoiding patent protection for plant varieties do face drawbacks. The main problem is that, while the 1978 version of the UPOV Convention had been widely interpreted as allowing farmers to save and exchange seed (Tancer and Tancer 1999: 907), the 1991 version does not allow this. As a result, there is concern amongst NGOs and developing country governments that global corporate actors such as Monsanto, one of the largest seed companies worldwide, will require farmers to purchase their seed and agree 
to monitoring of their crops to ensure that they are not retained and used for next year's planting (Tancer and Tancer 1999: 906).

In the light of growing concern about the impact of the 1991 version of the UPOV Convention there have been attempts by the African countries to alleviate the plight of farmers in developing countries by clarify the meaning of sui generis protection within Article 27.3(b) to provide for the continuation of traditional farming practices including the right to exchange and save seeds (see Tancer and Tancer 1999: 908). Meanwhile, from the perspective of global corporate actors, there are indications that the TABD will seek to take steps to encourage developed country governments to reduce the flexibility allowed under Article 27.3(b) during any future renegotiation of the TRIPs Agreement by insisting on more specific reference to the standards provided under the 1991 version of UPOV in relation to the types of sui generis protection available for plant varieties (see also Durán and Michalopoulos 1999: 864).

\section{WTO Members}

While developing countries made little contribution during the formulation of the TRIPs Agreement, save for adopting an early negotiating strategy of stating a preference for WIPO over GATT as the most appropriate forum for discussing intellectual property rights (see also Blakeney 2001: 537), as the impact of the TRIPs Agreement has become more widely understood the response from developing countries has become more pronounced. In formulating their response to the TRIPs Agreement, developing countries have, however, to some extent been hindered by an absence of reliable economic impact assessment (see also Watal 1999: 29) and arguably need a period of reflection now that the transitional period has come to an end in order to assess the actual implications, as opposed to the predicted impact, of the TRIPs Agreement. Nevertheless, developing countries have already begun to complain bitterly that developed countries have failed to take account of their obligations under Article 66.2 of the TRIPs Agreement to provide adequate incentives for businesses to promote technology transfer to developing nations. Developing countries have, according to Durán and Michalopoulos (1999: 866), sought to encourage technology transfer further by including a full review of the effectiveness of Article 66.2 implementation in any renegotiation of the Agreement. 
Applicant countries for WTO membership will also bring fresh implementation problems for the TRIPs Agreement. The People's Republic of China, for instance, received approval for its application for membership of the WTO at the Ministerial Meeting in Doha, Qatar, in November 2001. China is almost completely up to speed in legislative terms but still has major problems with intellectual property enforcement (see Dessler 1995). The Russian Federation, which also remains an applicant for WTO membership, has its own problems in relation to legislation giving effect to copyright protection that will need to be resolved.

\section{International institutions}

International institutions such as the World Health Organisation (WHO) have expressed particular concerns about the implications of higher prices of patented pharmaceutical products (see also Wilder 2001: 526). These organisations, together with NGOs such as Oxfam, ${ }^{30}$ have campaigned in support of South African plans to allow parallel imports and compulsory licensing to ensure access to medicines required locally to combat the HIV virus. In many respects, this debate on access to essential medicines has come to typify current anxieties about the impact of the TRIPs Agreement, with senior policy makers taking part in seminars on this topic, such as those organised jointly by the WHO and WTO Secretariats in April 2001, ${ }^{31}$ by the Royal Institute of International Affairs, London, in July 2001, ${ }^{32}$ and via special discussions on intellectual property and access to medicines within the TRIPs Council in June ${ }^{33}$ and September 2001. ${ }^{34}$

Some commentators have sought to encourage debate on whether the WHO or other international institutions can do anything to persuade developed countries and global corporate actors to display a more sensitive understanding of the needs of developing countries (Abbott 2001: 13), particularly where consumers in those countries are unable to pay the full price for proprietary pharmaceutical products (Wooldridge 2000: 111). But, conversely, there are also reports that global corporate actors have sought to exert pressure on international organisations such as WIPO, the WHO and UNCTAD with a view to constraining the advice given to developing countries to that of strict compliance with the TRIPs Agreement (Reichman 1998: 592).

In response to concerns about the implications of higher prices of patented pharmaceutical products, at the Fourth WTO Ministerial Conference in Doha, Qatar, on 14 November 2001 Members adopted a 'Declaration on the TRIPs Agreement and Public Health'. ${ }^{35}$ The 
Declaration recognised the gravity of the public health problems afflicting many developing and least-developed countries, especially those resulting from HIV/AIDS, tuberculosis, malaria and other epidemics. It stressed the need for the TRIPs Agreement to be part of the wider national and international action to address these problems. The Declaration recorded WTO Members agreement that TRIPs does not and should not prevent measures to protect public health and affirmed that the TRIPs Agreement should be interpreted and implemented in a manner supportive of WTO Members' right to protect public health and, in particular, to promote access to medicines for all.

Accordingly, the Declaration recognised the flexibilities contained in the TRIPs Agreement with respect to: the right to grant compulsory licences and the freedom to determine the grounds upon which such licences are granted; the right of each Member to determine what constitutes a national emergency or other circumstances of extreme emergency, it being understood that public health crises can represent a national emergency or other circumstances of extreme urgency; and the effect of provisions of the TRIPs Agreement which allow each Member freedom to establish its own regime for exhaustion of intellectual property rights, subject to the national treatment and most-favoured-nation treatment provisions of Articles 3 and 4 of the TRIPs Agreement. The Declaration then recognised that WTO Members with insufficient or no manufacturing capacities in the pharmaceutical sector could face difficulties in making effective use of compulsory licensing under the TRIPs Agreement and instructed the TRIPs Council to find an expeditious solution to this problem and to report to the General Council of the WTO before the end of 2002.

Finally, with particular regard to least-developed (but not developing) countries the Declaration reaffirmed the commitment of developed countries to provide incentives to their enterprises and institutions to promote and encourage technology transfer to least-developed countries pursuant to Article 66.2. Furthermore, under the terms of the Declaration, leastdeveloped country Members are not be obliged, with respect to pharmaceutical products, to implement the provisions of the TRIPs Agreement relating to patents (Section 5 of Part II) or the protection of undisclosed information (Section 7 of Part II) or to enforce rights provided for under these sections until 1 January 2016. This timescale is introduced without prejudice to the right of least-developed country Members to seek other extensions of the transitional periods as provided by Article 66.1. 
However, as Abbott (2001: 36) points out, while the Ministerial Declaration may well be useful as a near-term mechanism for addressing developing and least-developed country concerns, it will not carry the same weight as the TRIPs Agreement itself in the Dispute Settlement Procedure. In the longer term, negotiating amendments to the TRIPs Agreement during the Doha Development Round still remains a distinct possibility.

\section{DISPUTE SETTLEMENT PANELS}

Limits to the interpretation of the TRIPs Agreement also appear to have been set in relation to the 'legitimate expectations' doctrine as interpreted by the Appellate Body in the India-US Mailbox Dispute ${ }^{36}$. Reichman has been quick to acknowledge that, in the light of the Appellate Body report in the mailbox dispute, 'one can no longer argue that activist panels may fill the gaps in international intellectual property law by reference to the "legitimate expectations of members and private rights holders concerning conditions of competition"” (Reichman 1998: 596). The Appellate Body report appears to confirm that the TRIPs Agreement leaves developing countries free to introduce laws and policies in relation to intellectual property protection provided these were not expressly harmonized in the TRIPs standards themselves' (Reichman 1998: 597). It follows that 'developed countries are unlikely to prevail in actions for failure to respect the enforcement procedures of the TRIPs

Agreement unless they can show a pattern of flagrant violations....because developing countries need not provide foreign rights holders with a better quality of legal product than is available to their own citizens, which is usually poor by our standards' (Reichman: 1998: $598) .{ }^{37}$

\section{PROSPECTS FOR THE FUTURE: RENEGOTIATING THE TRIPS AGREEMENT?}

Given the likelihood is that any revision of the TRIPs Agreement will take place in the context of future WTO trade negotiations (see also Watal 1999: 29), as during the Uruguay Round negotiations intellectual property protection will in all probability be used in trade-offs in other sectors such as agriculture (see also Durán and Michalopoulos 1999: 865). One suggestion has been that developing countries should ensure that, in a move away from the package deals done during the Uruguay Round, any revisions of the TRIPs Agreement should be achieved on their own merits, with no bargaining across diverse trade issues (Gerhart 2000: 312). As net importers of intellectual property rights, developing countries should also 
occupy a negotiating stance as consumers, not producers, of intellectual property and in doing so form global alliances with NGOs, consumers, health care representatives and providers of educational facilities worldwide to devise a coherent and reasoned argument for improved access/lower royalty payments to technology protected by intellectual property rights.

\section{Developed country priorities}

Amendments to the TRIPs Agreement that would be desirable to global corporate actors, on the other hand, include tightening up the text, closing loopholes and adding omissions such as pipeline protection. The main issues for business interests are undoubtedly transitional periods, enforcement problems, and a willingness to prosecute for non-implementation.

Developed countries, in their communications to the WTO General Council in preparation for the 1999 Seattle Ministerial Conference, also made clear their priorities for further negotiation and/or review of the TRIPs Agreement. The United States ${ }^{38}$ proposed the including the issue of biotechnology patents and noted that Article 27.3(b) required the review of provisions allowing Members to exclude from patentability plants and animals four years after the entry into force of the WTO Agreement.

The European Communities ${ }^{39}$ noted that the 'built-in agenda' of TRIPS included a review of provisions on geographical indications, including a multinational register for wines, sprits and other products, explicitly stated that there should be no question of lowering standards or granting further transitional periods in any future negotiation of the TRIPs Agreement, noted that differences between the first-to-file and first-to-invent patent systems lead to unnecessary burdens for inventors, and called for the WTO to build upon international consensus reached by WIPO in the field of copyright and related rights and in the context of the information society. On this latter point, intellectual property rights in relation to electronic commerce are not at present covered by the TRIPs Agreement (see also Ryan 1998: 199). In 1996 WIPO concluded the Copyright Treaty ${ }^{40}$ (which deals in particular with on-line communications through the internet) and the Performances and Phonograms Treaty. ${ }^{41}$ The EC has subsequently adopted a Directive on copyright in order to implement the WIPO treaties, while the US has introduced the Digital Millennium Copyright Act. ${ }^{42}$ There have hence been discussions about incorporating these treaties within any future revision of the TRIPs Agreement. 
$\operatorname{Japan}^{43}$ called for full implementation of the TRIPs Agreement and shared to priorities of the European Communities in relation to patent harmonisation around the first-to-file system, the need for the TRIPs Agreement to take account of higher levels of protection achieved in other treaties or conventions (presumably the WIPO copyright treaties) and reiterated that any negotiations should not discuss reducing the current level of protection for intellectual property rights (see also Watal 1999: 6).

\section{Developing country priorities}

Many developing countries and those actors, including NGOs, expressing concerns about the impact of the TRIPs Agreement see the built-in agenda and the opportunity for the TRIPs Council to review the application of the TRIPs Agreement as offering some prospect of renegotiation and relief from the costs of compliance. The built-in agenda, it will be recalled, required that a review of Articles 22.1, 23.4, 24.1 and 27.3(b) commence in 1999. These provisions concern unresolved issues from the Uruguay Round negotiations relating to geographical indications (Articles 22.1, 23.4 and 24.2) and a review of patent protection for plants and animals other than microorganisms and sui generis protection for plant varieties (Article 27.3(b)). Moreover, Article 71.1 of the Agreement provides for the TRIPs Council to review its implementation after the expiry of the 1 January 2000 deadline for the ending of the transitional period for developing countries and every two years thereafter (see Article 65.2) (Durán and Michalopoulos 1999: 853).

There are, however, different interpretations as to how the review of the built-in agenda should be conducted. Grubb's (1999: 46) opinion on the review of Article 27.3(b), for instance, is that it should be strictly on the narrow issue of whether the exclusion of plants and animals from patentability should be retained in the TRIPs Agreement, although there are concerns that environmental NGOs and some developing countries will use the built-in review as a 'foot in the door' to renegotiate the TRIPs Agreement more widely. Equally, it has been claimed by developing countries that, according to the first sentence of Article 71.1, a review of the entire TRIPs Agreement should have been initiated in the year 2000. Grubb (1999: 47) and Blakeney (2001: 534), however, interpret the provisions of Article 71.1 merely as referring to a review of TRIPs implementation since it would make no sense to commence renegotiation of the Agreement before full implementation has been achieved and its impacts properly assessed. 
In relation to sui generis protection, the review of Article 27.3(b) has already begun within the TRIPs Council as part of the built-in agenda of the Agreement. It should be borne in mind that this issue was not settled definitively during the Uruguay Round negotiations because of differences between the US and EC positions (see also Watal 1999: 5) rather than because of recognition of developing country opposition to the patenting of plants and animal inventions. Although the United States remains keen on identifying the UPOV Convention as the reference treaty for the interpretation of sui generis proection, environmental NGOs, wholly absent from the original TRIPs Agreement negotiations, are now actively campaigning for the whole of Article 27.3 to be deleted (Blakeney 2001: 537) on grounds of morality and ethics. Developed countries are reluctant to re-appraise the status of Article 27.3(b), particularly with the issue still not fully resolved internally within the European Communities (Watal 1999: 9).

Developing countries are also concerned about possible discrepancies between the UN Convention on Biodiversity (CBD) ${ }^{44}$ and the TRIPs Agreement. The CBD recognises that nations have sovereignty over biological resources and acknowledges the benefits of equitable sharing of any benefits arising from these resources or from traditional knowledge related to biological diversity (see also Durán and Michalopoulos 1999: 867). Developing countries, including India ${ }^{45}$, Kenya ${ }^{46}$ and Venezuela, ${ }^{47}$ have already suggested that the TRIPs Agreement should be re-examined to reconcile any differences between TRIPs and the CBD, particularly in relation to Article 27.3(b) in order to prohibit the granting of patents to those inventions made with foreign genetic material that are inconsistent with Article 15 of the CBD relating to the recognition of sovereignty and access to genetic resources (Wilder 2001: 521). But although the issues of biodiversity are likely to remain emotive and high on the agenda of any debate about revision of the TRIPs Agreement, developed countries are reluctant to reopen the debate in the face of strong public campaigns from NGOs.

In other areas, developing countries have sought to use the built-in review to their advantage, even when the issues relate primarily to developed country interests. Geographical indications, for instance, that were originally included in the TRIPs Agreement on the insistence of the EC and Switzerland are now being taken seriously by developing countries as part of the built-in review as a possible means of protecting regionally-specific handicrafts, foodstuffs and agricultural produce (see also Blakeney 2001: 541). 


\section{LIKELY OUTCOMES}

The TRIPs Agreement contains compromises and is imperfect in many respects. The nature of some of these compromises are recognised by the built-in agenda for the Agreement. According to Article 27(3)(b), for instance, its provisions were to be reviewed by the TRIPs Council four years after the entry into force of the Agreement. But there is no consensus on whether this review should be with respect to substantive issues or merely implementation. Tancer and Tancer (1999: 904) argue that it would be illogical to have implementation as the basis for the review given that developing countries had until five years after the entry into force of the Agreement (and ten years in the case of least-developed countries) before they were required to comply with its provisions.

The most likely outcome of attempts to revise the TRIPs Agreement is that, in the medium term, no substantive revision of the TRIPs Agreement will be made (see also Watal 1999: 29). The Seattle Ministerial of 1999 ended without agreement on substantive issues, which remain on the table for future discussion, and developed countries remain of the opinion that the provisions of the TRIPs Agreement should not be tampered with, the focus of any review instead being instead on enforcement and implementation questions (see also Tancer and Tancer 1999: 892), particularly in the light of findings made by the TRIPs Council via the Article 63(2) review procedure (Blakeney 2001: 535) and Dispute Settlement Panels (see also Watal 1999: 1). The developed countries do, however, want to see revisions to the TRIPs Agreement in terms of a tightening up of the text. Tim Trainer, President of the AntiCounterfeiting Coalition, for instance, has predicted (Anon. 1999: 5) that parts of the TRIPs Agreement may have to be looked at again with respect to anti-counterfeiting measures, where ambiguities in the language of Articles 51 to 60 on border measures are seen as leading to difficulties in determining the correct interpretation of the provisions.

\section{ASSESSMENT}

There is a widespread acknowledgement amongst corporate actors that, given the achievements of the Uruguay Round negotiations with regard to intellectual property protection, it is perhaps churlish to criticise the final text of the TRIPs Agreement for its shortcomings. However, what is clear is that, in many important respects, the negotiating space that granted global corporate actors and developed country governments a relatively 
'free run' during the Uruguay Round has now been occupied by a range of new actors bringing their own issues, priorities and concerns to the negotiating table. Despite the postTRIPs initiatives undertaken by the TABD, IPC-UNICE and developed country governments, the window of opportunity that emerged when global corporate actors seized the initiative and galvanized a broad range of interests in support of intellectual property protection during the Uruguay Round seems unlikely to be re-opened.

\section{Endnotes}

${ }^{1}$ According to Jacques Gorlin, Consulting Economist, The Gorlin Group, and co-ordinator of the Intellectual Property Committee. Interview with the author, Washington DC, 1 April 1998.

${ }^{2}$ In addition, a number of other business associations have been identified as playing a significant role in the Special 301 process: the Computer Software and Services Industry Association, the Business Software Alliance, the Pharmaceutical Manufacturers Association, the Chemical Manufacturers Association, the National Agricultural Chemicals Association, the Motor Equipment Manufacturers Association, the Auto Exports Council, Intellectual Property Owners Inc., and the Semiconductor Industry Association (Sell 1995: 166).

${ }^{3}$ According to Jacques Gorlin. Interview with the author, Washington DC, 1 April 1998. See also the accounts events given by Drahos 1995: 12; Enyart 1990: 54 and Sell 1998: 137.

4 The significance of the role played by European business interests in drafting proposals for a framework of GATT provisions on intellectual property was the subject of a discussion between the author and John Beton, President of the Trade Mark Patent and Design Federation in the UK (1983-1985) and Chairman of the UNICE Intellectual Property Working Group, conducted at the University of Warwick, 7 April 1998.

5 According to Jacques Gorlin, Consulting Economist, The Gorlin Group and co-ordinator of the Intellectual Property Committee. Interview with the author, Washington DC, 1 April 1998.

${ }^{6}$ According to one senior executive of a company that was formerly an IPC member, before the TRIPs Agreement was concluded the annual fee for membership of the IPC was $\$ 40,000$ per annum. This was reduced to $\$ 25,000$ per annum for each company after conclusion of the TRIPs Agreement. Interview with the author 31 March 1998.

${ }^{7}$ In the domestic context, US businesses (both large and small firms) and universities also make their views know to policy makers through their membership of the Intellectual Property Owners (IPO), another single-issue group which lobbies on behalf of its members in Washington DC.

${ }^{8}$ Letter from the Eric Smith, President of the International Intellectual Property Alliance, to Joseph Papovich, Assistant USTR for Services, Investment and Intellectual Property, 23 February 1998. A copy of the letter was given to the author by Eric Smith on 2 April 1998.

${ }^{9}$ These reported losses are estimates calculated on the basis of information provided by the International Intellectual Property Alliance's member associations. Although not independently corroborated, the IIPA has stated its belief that these estimates actually underestimate losses due to piracy by the US copyright-based industries.

${ }^{10}$ In 1998 the PhRMA began its communication to member companies, requesting the completion of a fax-back form indicating countries where inadequate patent protection for pharmaceutical products had been identified, with the suggestion that 'As we approach the end of January and the middle of a Washington winter, we are reminded that it is "Special 301" Season again.' Memo from the Pharmaceutical Research and Manufacturers of America, 28 January 1998.

${ }^{11}$ Submission of the Pharmaceutical Research and Manufacturers of America for the 'Special 301' Report on Intellectual Property Barriers 1998. 13 February 1998.

${ }^{12}$ The United States finally initiated a complaint against Argentina under the WTO dispute settlement procedure on 6 May 1999, alleging an infringement of Articles 27, 65(2) and 70(9) of the TRIPs Agreement in respect to patent protection for pharmaceutical products, WT/DS171/1.

${ }^{13} \mathrm{WT} / \mathrm{DS} 86 / 2$.

${ }^{14}$ On 14 May 1997 the US also requested consultations with Denmark in respect to Articles 50, 63 and 65 of the TRIPs Agreement.

${ }^{15} \mathrm{WT} / \mathrm{DS} 125 / 1$.

${ }^{16} \mathrm{WT} / 124 / 1$. 
${ }^{17}$ WT/DS160.

${ }^{18}$ The website of the Transatlantic Business Dialogue can be found at http://www.tabd.com/ (8 October 2001).

${ }^{19}$ Differences between the US and EC on first-to-invent and first-to-file are also highlighted in the TABD1988 Mid-Year Report and Scorecard.

${ }^{20}$ Draft Communication from the Commission to the Council, the European Parliament and the Economic and Social Commission on The New Transatlantic Marketplace from Sir Leon Brittan, Martin Bangemann and Mario Monti, 11 March 1998.

${ }^{21}$ Ibid 19.

${ }^{22}$ The concerns of the IPC and UNICE were, to some extent, confirmed by the request for an extension to the transitional period allowed under Article 65 made by Cuba, the Dominican Republic, Egypt and Honduras (WT/GC/W/209) (quoted in Wilder 2001: 516).

${ }^{23} \mathrm{WT} / \mathrm{DS} / 152 / \mathrm{R}, 22$ December 1999.

${ }^{24} \mathrm{WT} / \mathrm{DS} 160 / \mathrm{R}, 15$ June 2000.

${ }^{25}$ WT/DS170/AB/R. 18 September 2000.

26 See, for example, the World Trade Organisation statement on NGOs at http://www.wto.org/english/forums_e/ngo_e/intro_e.htm (29 October 2001).

${ }^{27}$ The website for the International Forum on Globalization can be found at http://www.ifg.org/ (11 September 2001).

${ }^{28}$ The website for Public Citizen can be found at http://www.citizen.org/ (11 September 2001).

${ }^{29}$ Nevertheless, a flaw in the arguments of those opposing the TRIPs Agreement is that the gathering of empirical evidence to support propositions concerning the costs and benefits of developing country compliance with the TRIPs Agreement has been 'largely lacking' (Bronkers 1994: 1248), although a notable recent exception is Maskus (2000).

30 'Oxfam Urges Charitable Stance on Drugs Patents', Financial Times, 12 February 2001, page 6; 'Drugs Companies in Challenge to South Africa Over Patent Rights', Financial Times, 5 March 2001, page 11.

31 A joint WHO/WTO/Norwegian Foreign Affairs Ministry/Global Health Council workshop was held at Hosbjor, Norway, from 8 to 11 April 2001 to discuss 'Differential Pricing and Financing of Essential Drugs'. At the meeting, attended by experts rather than government representatives, participants called for improved funding for essential drugs in developing countries. The final report of the workshop is available on the World Trade Organisation website at: http://www.wto.org/english/tratop_e/trips_e/tn hosbjor_e.htm\#finalreports (23 August 2001).

32 'The Economics of Essential Medicine' seminar held at the Royal Institute of International Affairs, Chatham House, London on 10 July 2001.

${ }^{33}$ A report on the first discussion of the TRIPs Council on 'Intellectual Property and Access to Medicines' that took place on 20 June 2001 can be found on the WTO website at: http://www.wto.org/english/tratop_e/trips_e/counciljun01 e.htm (20 October 2001).

${ }^{34}$ A report on the second discussion of the TRIPs Council on 'Intellectual Property and Access to Medicines' that took place 19 and 21 September 2001, can be found on the WTO website at: http://www.wto.org/english/tratop_e/trips_e/councilsep01_e.htm (12 October 2001).

${ }^{35} \mathrm{WT} / \mathrm{MIN}(01) / \mathrm{DEC} / \mathrm{W} / 2$.

${ }^{36} \mathrm{WT} / \mathrm{DS} 50 / \mathrm{AB} / \mathrm{R}$

${ }^{37}$ Reichman does, however, acknowledge that there is a countervailing risk that a developed country, such as the United States, might resort to unilateral pressures under Section 301 or a similar measure in other developed countries (Reichman 1998: 598).

${ }^{38} \mathrm{WT} / \mathrm{GC} / \mathrm{W} / 115,19$ November 1998.

${ }^{39} \mathrm{WT} / \mathrm{GC} / \mathrm{W} / 193,2$ June 1999.

${ }^{40}$ A copy of the WIPO Copyright Treaty is available on the World Intellectual Property Organisation website at http://www.wipo.int/treaties/ip/copyright/index.html (7 September 2001).

${ }^{41}$ A copy of the WIPO Performances and Phonograms Treaty is available on the World Intellectual Property Organisation website at http://www.wipo.int/treaties/ip/performances/index.html (7 September 2001).

42 A copy of the Digital Millennium Copyright Act is available on the Electronic Frontier Foundation website at http://www.eff.org/ip/DMCA/hr2281_dmca law_19981020_pl105-304.html (7 September 2001).

${ }^{43} \mathrm{WT} / \mathrm{GC} / \mathrm{W} / 242,6$ July 1999.

${ }^{44}$ See http://www.biodiv.org/ (7 September 2001).

${ }^{45} \mathrm{WT} / \mathrm{GC} / \mathrm{W} / 225,2$ July 1999.

${ }^{46} \mathrm{WT} / \mathrm{GC} / \mathrm{W} / 302$.

${ }^{47} \mathrm{WT} / \mathrm{GC} / \mathrm{W} / 282$ 


\section{BIBLIOGRAPHY}

Abbott, F.M. (1996) 'The WTO TRIPS Agreement and Global Economic Development', Chicago Kent Law Review 72: 385-404.

(2001) 'The TRIPs Agreement, Access to Medicines and the WTO Doha Ministerial Conference, Florida State University College of Law, Public Law and Legal Theory Working Paper No. 36.

Anon. (1999) 'Seattle Leaves Issues Unresolved', Managing Intellectual Property 95: 5.

Bello, J.H. (1997) 'Some Practical Observations About WTO Settlement of Intellectual Property Disputes', Virginia Journal of International Law 37: 336-367.

Blakeney, M. (1995) 'Intellectual Property in World Trade', International Trade Law and Regulation 1, 3: 76-81.

— (1996) Trade-Related Aspects of Intellectual Property Rights: A Concise Guide to the TRIPs Agreement, London: Sweet and Maxwell.

(2001) 'Intellectual Property in the Millennium Round - the TRIPs Agreement After Seattle, in Fletcher, I., Mistelis, L. and Cremona, M. Foundations and Perspectives of International Trade Law, London: Sweet and Maxwell.

Braithwaite J. and Drahos, P. (2000) Global Business Regulation, Cambridge, UK: Cambridge University Press.

Dessler, D. (1995) 'China's Intellectual Property Protection: Prospects for Achieving International Standards', Fordham International Law Journal 19: 181-246.

Dörmer, S. (2000) 'Dispute Settlement and New Developments Within the Framework of TRIPs - An Interim Review', International Review of Industrial Property and Copyright Law 31,1: 1-36.

Drahos, P. (1995) 'Global Property Rights in Information: The Story of TRIPs at the GATT', Prometheus 13, 1: 6-19.

(1997) 'Thinking Strategically About Intellectual Property Rights', Telecommunications Policy 21, 3: 201-211.

Durán, E. and Michalopoulos, C. (1999) 'Intellectual Property Rights and Developing Countries in the WTO Millennium Round', Journal of World Intellectual Property 2, 6: 853874.

Enyart, J.R. (1990) ‘A GATT Intellectual Property Code’, les Nouvelles June: 53-56.

Evans, G.E. (1994) 'Intellectual Property as a Trade Issue: the Making of the Agreement on Trade-Related Aspects of Intellectual Property Rights', World Competition 18, 2: 137-180. 
Gerhart, P.M. (2000) 'Why Lawmaking for Global Intellectual Property is Unbalanced', European Intellectual Property Review 22, 7: 309-313.

Geuze, M. and Wager, H. (1999) 'WTO Dispute Settlement Practice Relating to the TRIPs Agreement', Journal of International Economic Law: 347-384.

Gorlin, J. (1999) An Analysis of the Pharmaceutical-related Provisions of the WTO TRIPs (Intellectual Property) Agreement, London: Intellectual Property Institute.

Grubb, P.W. (1999) Patents for Chemicals, Pharmaceuticals and Biotechnology. Fundamentals of Global Law, Practice and Strategy, Oxford: Oxford University Press.

Gutowski, R.J. (1999) 'The Marriage of Intellectual Property and International Trade in the TRIPs Agreement: Strange Bedfellows or a Match Made in Heaven?', Buffalo Law Review 47: 713-761.

IIPA (1985) Piracy of US Counterfeited Goods in Ten Selected Countries, Washington DC: IIPA.

— (1998) Special 301 Recommendations Submitted to the United States Trade Representative on 23 February 1998, Washington DC: IIPA.

International Trademark Association (1999) 'Developing Countries' Compliance with the TRIPS Agreement', http://inta.org/TRIPS2000.htm (8 February 2001).

Macdonald-Brown, C. and Ferera, L. (1998) 'First WTO Decision on TRIPs' European Intellectual Property Review 2: 69-73.

Maskus, K.E. (2000) Intellectual Property Rights in the Global Economy, Washington D.C.: Institute for International Economics.

May, C. (2000) A Global Political Economy of Intellectual Property Rights. The new enclosures?, London: Routledge.

Newell, P. (2000) 'Environmental NGOs and Globalization: The Governance of TNCs', in Cohen, R. and Rai, S.M. (eds.) Global Social Movements, London: Athlone Press.

O'Regan, M. (1995) 'The Protection of Intellectual Property, International Trade and the European Community: The Impact of the TRIPS Agreement of the Uruguay Round of the Multilateral Trade Negotiations', Legal Issues in European Integration 2: 1-50.

Pacón, A.M. (1996) 'What will TRIPS do for Developing Countries?', in Beier, F-K and Schreiker, G. 'From GATT to TRIPs: the Agreement on Trade-related Aspects of Intellectual Property Rights', Special Edition International Review of Industrial Property and Copyright Law 18: 329-357. 
Reichman, J.H. (1995) 'Universal Minimum Standards of Intellectual Property Protection under the TRIPs Component of the WTO Agreement', The International Lawyer, 29, 2: 345390.

(1996) 'Compliance with the TRIPs Agreement: Introduction to a Scholarly Debate', Vanderbilt Journal of Transnational Law 29,3: 366-390.

_ (1998) 'Securing Compliance with the TRIPs Agreement after US v India', Journal of International Economic Law 1,4: 585-601.

Ryan, M.P. (1998) Knowledge Diplomacy: Global Competition and the Politics of Intellectual Property, Washington DC: The Brookings Institution.

Sell, S.K. (1995) 'The Origins of a Trade-Based Approach to Intellectual Property Protection: the Role of Industry Associations', Science Communication 17, 2: 163-185.

(1998) Power and Ideas. The North-South Politics of Intellectual Property and Antitrust, New York: State University of New York Press.

Stewart, T.P. (ed.) (1993) The GATT Uruguay Round. A Negotiating History (1986-1992), Deventer, Netherlands: Kluwer Law and Taxation Publishers.

Tancer, R.S. and Tancer, S.B. (1999) 'TRIPS in the Millennium Round', Journal of World Intellectual Property 2, 6: 889- 910.

Watal, J. (1999) 'TRIPS and the 1999 WTO Millennium Round', Journal of World Intellectual Property 3, 1: 1-29.

Waters, D.M. (1996) 'Enforcement: an industrial view', Chartered Institute of Patent Agents Journal 25: 766-772.

Weissman, R. (1996) 'A Long, Strange TRIPs: The Pharmaceutical Industry Drive to Harmonize Global Intellectual Property Rules, and the Remaining WTO Legal Alternatives Available to Third World Countries', University of Pennsylvania Journal of International Economic Law 17, 4: 1069-1125.

Wilder, R. (2001) 'Global Harmonisation of Intellectual Property', in Fletcher, I., Mistelis, L. and Cremona, M. Foundations and Perspectives of International Trade Law, London: Sweet and Maxwell.

Wooldridge, F. (1997) TRIPS and Enforcement, London: Intellectual Property Institute. 